\title{
A STUDY ON RELATION OF THYROID STIMULATING HORMONE LEVEL WITH SKELETAL METASTASIS IN CARCINOMA PROSTATE PATIENTS
}

\author{
Minaxi Sharma1, Krishna Gopal Sharmaㄹ, Deepak Sethi ${ }^{3}$, Rajveer Singh ${ }^{4}$, Anjali Sethi ${ }^{5}$
}

${ }^{1}$ Assistant Professor, Department of Surgery, Rabindranath Tagore Medical College, Udaipur, Rajasthan.

${ }^{2}$ Assistant Professor, Department of Surgery, Rabindranath Tagore Medical College, Udaipur, Rajasthan.

${ }^{3}$ Consultant Surgeon and Sr. Specialist, Department of Surgery, Rabindranath Tagore Medical College, Udaipur, Rajasthan.

${ }^{4}$ Resident Doctor, Department of Surgery, Rabindranath Tagore Medical College, Udaipur, Rajasthan.

${ }_{5}^{5}$ Associate Professor and HOD, Department of Surgery, Ananta Institute of Medical Sciences, Kaliwas, Tehsil Nathdwara, Rajasthan.

ABSTRACT

\section{BACKGROUND}

Prostate, a genital organ, secretes fluid, seminal plasma, the possible function of which is to provide nutrition to the sperms and serve as their vehicle during ejaculation. Prostate is of great clinical importance because of its affinity for inflammatory, congestive, hyperplastic and neoplastic diseases. Majority of instances of prostatic pathology are manifested by derangement of urination owing to the intimate anatomical relationship between urinary bladder and prostate. We studied serum TSH Levels in patients of $\mathrm{BPH}$ and CA prostate and its relation with skeletal metastasis.

This descriptive study was aimed to study any correlation between Serum TSH level and bone metastasis in patients with Prostate carcinoma.

\section{MATERIALS AND METHODS}

This descriptive study was conducted at Rabindranath Tagore Medical College and Maharana Bhupal Government Hospital, Udaipur, Rajasthan in the Department of Surgery. A non-statistical sample size of 50 patients suffering from benign prostatic hyperplasia or prostate cancer was taken as per convenience. The patients were divided into 2 groups, 25 patients of BPH based on serum PSA estimation (control) and 25 patients of prostate cancer based on serum PSA estimation (test). Preoperative estimation of serum TSH and serum PSA was done in all the patients. All the patients were operated (TURP or palliative TURP). The results of serum TSH, serum PSA, and Gleason score were then analysed and a relation between increasing levels of serum TSH, serum PSA, and Gleason grade was sought based on exploratory data analysis (EDA).

\section{RESULTS}

Serum PSA level in most of the BPH patients was found to be within normal limit and serum TSH level in all of the BPH patients was found to be within normal limits. Only in $8 \%$ cases of Prostate carcinoma patients had very high PSA level (>100 ng/mL) as well as increased serum TSH level and it was associated with Gleason score 8 (high-grade tumour) and skeletal metastases. Further statistical/epidemiological studies are required for confirmation of these findings.

\section{CONCLUSION}

Only in $8 \%$ cases of Prostate carcinoma patients had a very high PSA level ( $>100 \mathrm{ng} / \mathrm{mL}$ ) as well as increased serum TSH level, and it was associated with Gleason score 8 (high-grade tumour) and skeletal metastases. Further statistical/epidemiological studies are required for confirmation of these findings.

\section{KEYWORDS}

Prostate Carcinoma, Serum PSA, Serum TSH, Benign Prostatic Hyperplasia (BPH).

HOW TO CITE THIS ARTICLE: Sharma M, Sharma KG, Sethi D, et al. A study on relation of thyroid stimulating hormone level with skeletal metastasis in carcinoma prostate patients. J. Evolution Med. Dent. Sci. 2017;6(79):5619-5625, DOI: $10.14260 /$ jemds/2017/1219

\section{BACKGROUND}

Prostate, a genital organ, secretes fluid, seminal plasma, the possible function of which is to provide nutrition to the sperms and serve as their vehicle during ejaculation.

Prostate is of great clinical importance because of its affinity for inflammatory, congestive, hyperplastic and neoplastic diseases.

'Financial or Other Competing Interest': None.

Submission 26-08-2017, Peer Review 18-09-2017,

Acceptance 25-09-2017, Published 30-09-2017.

Corresponding Author:

Dr. Krishna Gopal Sharma,

Flat No. 306, Tak Complex,

Above Reliance Fresh Store,

Fatehpura, Udaipur-313001.

E-mail: kghsarma576@gmail.com, deepanjali.d1972@gmail.com DOI: $10.14260 / \mathrm{jemds} / 2017 / 1219$
Majority of instances of prostatic pathology are manifested by derangement of urination owing to the intimate anatomical relationship between urinary bladder and prostate.

Prostate specific antigen (PSA) is a glycoprotein that is a serine protease. Its function may be to facilitate liquefaction of semen, but it is a marker for prostatic disease. It is measured by an immunoassay. The normal upper limit of PSA is about $4 \mathrm{ng} / \mathrm{mL}$. Men with locally confined prostate cancer usually have serum PSA levels $<15 \mathrm{ng} / \mathrm{mL}$. Its level in men with metastatic prostate cancer usually increased to $>30$ $\mathrm{ng} / \mathrm{mL}$.

Human TSH on the other hand is a glycoprotein that contains 211 amino acids residue, plus hexoses, hexosamines and sialic acid. The biologic half-life of human TSH is about 60 min. The normal secretion rate is about $110 \mu \mathrm{g} /$ day. The average plasma level is about $2 \mu \mathrm{IU} / \mathrm{mL}$, which is produced 
by the anterior pituitary and directly controls production and release of thyroid hormones by thyroid follicles. The established function of thyroid stimulating hormone (TSH) is to promote thyroid follicle development and hormone secretion. The osteoporosis associated with hyperthyroidism is traditionally viewed as a secondary consequence of altered thyroid function. ${ }^{[1]}$

Bone metastasis is a frequent, serious and costly complication of cancer, occurring in up to 70 percent of patients with advanced prostate cancer. Bone metastasis in prostate cancer are predominantly osteoblastic, which may present as bone pain and pathologic fractures because of the poor quality of bone produced by the osteoblasts. ${ }^{[2]}$

The Mechanism of Osteoblastic Metastasis may be due to-

i. Overproduction of urokinase-type plasminogen activator $(\mu-\mathrm{PA})$ by prostate cancer cells with increased bone metastases.

ii. By releasing PSA, (a Kallikrein serine protease) by prostate cancer cells with increased bone metastases. PSA can cleave parathyroid hormone related peptide, released by tumour cells at $\mathrm{N}$-terminal. This cleavage may block tumour-induced bone resorption. In patients with prostate cancer, high PSA levels are associated with bone metastases, but levels of bone resorption marker are also high in patients with bone metastases.

iii. By releasing parathyroid hormone related peptide (PTH-rP), (a protein) by prostate cancer cells with increased bone metastases. It may also activate osteoblastic growth factors released in the bone microenvironment during the development of bone metastases, such as insulin-like growth factors I and II or transforming growth factor $\beta$.

iv. By releasing TSH, (a glycoprotein) by prostate cancer cells with increased bone metastasis. TSH directly affects both components of skeletal remodelling osteoblastic bone formation and osteoclastic bone resorption, mediated via the TSH receptor (TSHR) found on osteoblast and osteoclast precursors. Even a $50 \%$ reduction in TSHR expression produces profound osteoporosis (bone loss) together with focal osteosclerosis (localised bone formation). TSH inhibits osteoclast formation and survival by attenuating $\mathrm{JNK} / \mathrm{c}$-jun and $\mathrm{NF}_{\mathrm{K}} \mathrm{B}$ signalling triggered in response to receptor activator of nuclear factor-кB ligand (RANKL) and tumour necrosis factor $\alpha(\mathrm{TNF} \alpha)$. TSH also inhibits osteoblast differentiation and type 1 collagen expression. A role has thus been defined for TSH as a single molecular switch in the independent control of both bone formation and resorption. ${ }^{11]}$

v. By activation of PTH and calcitonin receptor (seven transmembrane $G$ protein coupled receptor). The calcitonin receptor is expressed on both osteoclasts and osteoblasts, its primary function is inhibition of bone resorption, decreasing osteoclast motility and secretion, by osteoclasts of acid and proteases.

The PTH- receptor is highly expressed only on osteoblasts, which PTH impacts in biphasic manner. Specifically, intermittent administration of the hormone enhances bone formation, and continuous exposure increases RANKL expression, thereby favouring osteoclast differentiation and bone resorption. The TSH, calcitonin and PTH (bone active seven transmembrane receptors), each of them signals through C-AMP, phospholipase C, and protein Kinase A.

Gleason Grading System- The Gleason grading method was devised in the 1960s and 1970s by Dr Donald F. Gleason and members of the Veterans Administration Cooperative Urological Research Group. This grading system is based entirely on the histologic pattern of arrangement of carcinoma cells in H\&E-stained sections. Five basic grade patterns are used to generate a histologic score, which can range from 2 to 10. [3] $^{[3]}$

Gleason Grading System is a Microscopic Grading System. It is based on the Degree of Glandular differentiation and the Growth Pattern of the Tumour in Relation to Stroma. It is divided into five Grades-

1. Grade-1: Represents the well-differentiated tumours, in which the neoplastic glands are uniform and round in appearance and are packed in to well-circumscribed nodules.

2. Grade-5: Represents no glandular differentiation and the tumour cells infiltrate the stroma in the form of cords, sheets and nests.

3. The other grades fall in between.

Most common tumours contain more than one pattern, in which case one assigns a primary grade to the dominant pattern and a secondary grade to the subdominant pattern. The two numeric grades are then added to obtain a combined Gleason grade or score. Thus, for example, a tumour with a dominant grade 3 and a secondary grade 4 would achieve a Gleason score of 7 .

Thus, under this scheme Gleason scores are often combined into groups-

1. Score of 2 to 4 representing well-differentiated cancer.

2. Score of 5 to 6 representing intermediate-grade cancer.

3. Score of 7 representing moderate-to-poorly differentiated cancer.

4. Score of 8 to 10 representing high-grade cancer.

The majority of potentially treatable cancer patients have Gleason scores of 5 to 7. Tumours with Gleason scores 8 to 10 tend to be advanced cancers that are unlikely to be curable.

Grading is of particular importance in prostatic cancer because it is the best marker along with the stage, for predicting prognosis.

Men with Gleason 8 prostate cancer (High-grade tumour) have a high risk of bone metastases, by increased release of TSH by prostate cancer cells, which (TSH) further suppresses both osteoblast and osteoclast differentiation by exerting control over bone remodelling. However, with abnormally high TSH levels, this process may become deranged, promoting the development of bone metastasis. If TSH production by prostate cancer cells could be suppressed, the incidence of bone metastases might be reduced.

The Gleason grading system for prostate adenocarcinoma has evolved from its original scheme established in the 1960s-1970s, to a significantly modified system after two major consensus meetings conducted by the International Society of Urologic Pathology (ISUP) in 2005 and 2014, respectively.[4]

The incidence of prostate cancer in men 50-69 years has increased substantially since $1970 \mathrm{~s} .{ }^{[5]}$ 
We studied serum TSH Levels in patients of BPH and CA prostate and its relation with skeletal metastasis.

\section{Aims and Objectives}

This descriptive study was aimed to study any correlation between Serum TSH level and bone metastasis in patients with Prostate carcinoma.

\section{MATERIALS AND METHODS}

This descriptive study was conducted at Rabindranath Tagore Medical College and Maharana Bhupal Government Hospital, Udaipur, Rajasthan in the Department of Surgery.

A non-statistical sample size of 50 patients suffering from benign prostatic hyperplasia or prostate cancer was taken as per convenience.

The diagnosis was made by a combination of history, detailed clinical examination including digital rectal examination (DRE) and lymph node examination, radiological films of chest and pelvis and serum PSA levels. Serum TSH was estimated in all the patients.

The Patients were divided into 2-Groups of 25 each-

- Group A: 25 patients of BPH based on serum PSA estimation (control)

- Group B: 25 patients of prostate cancer based on serum PSA estimation (test).

Preoperative estimation of serum TSH and serum PSA was done in all the patients. All the patients were operated (TURP or palliative TURP). Postoperatively tissue biopsy was histopathologically examined in all the cases and grading was done based on the Gleason Scoring System.

The resultant data of serum TSH, serum PSA, and Gleason score were then analysed and a relation between increasing levels of serum TSH, serum PSA, and Gleason grade was sought based on exploratory data analysis (EDA).

\section{RESULTS}

A Total of 50 patients were studied, of which 25 were BPH Patients and 25 were CA Prostate. Age distribution of our patients was as per Table 1 .

Most of the cases of BPH patients belonged to rural population i.e., $64 \%$ and $36 \%$ belonged to urban population. Most of the cases of Prostate carcinoma patients belonged to rural population i.e., $76 \%$ and $24 \%$ belonged to urban population.

In BPH, all of the patients had complaints of sensation of incomplete emptying of urinary bladder, weak urinary stream and hesitancy (100\%) followed by frequency, intermittency and nocturia (92\%), urgency (88\%), dysuria (76\%), burning micturition (40\%), retention of urine $(28 \%)$ and haematuria in $16 \%$ cases.

In Prostate carcinoma, all of the patients had complaints of sensation of incomplete emptying of urinary bladder, weak urinary stream and hesitancy (100\%) followed by frequency and nocturia (96\%), intermittency and urgency (92\%), dysuria (88\%), burning micturition (76\%), haematuria $(20 \%)$ and retention of urine in $16 \%$ cases.

AUA score of patients of BPH and CA-prostate are shown in Table 2 and Table 3.

Other associated symptoms in cases of BPH/Prostate carcinoma are given in Table 4.
Blood Urea and Serum Creatinine levels of the patients were as per Table 5 and Table 6 respectively.

In $\mathrm{BPH}, 84 \%$ cases were vegetarians and $48 \%$ were smokers and $12 \%$ were alcoholics.

In Prostate carcinoma, $72 \%$ cases were vegetarians, $64 \%$ were smokers and $28 \%$ were alcoholics.

Findings of DRE were as per Table 7.

Findings of cystoscopy were as per Table 8.

USG findings of the patients were as per Table 9.

X-ray KUB findings in cases of BPH and CA-prostate patients is as per Table 10 .

X-ray KUB finding in BPH patients were normal KUB in most of the cases of BPH i.e., 23 cases (92\%). In only 2 cases i.e., $8 \%$ cases, there was left ureteric stone present.

X-ray KUB finding in Prostate carcinoma patients- normal KUB was found in most of the Prostate carcinoma cases i.e., $84 \%$ (21 cases). There was left ureteric stone in $4 \%$ cases and left renal stone in $4 \%$ cases. In $8 \%$ cases, osteoblastic secondaries were seen in iliac bone.

Serum PSA level, in BPH patients was found to be normal in 10 cases i.e. $40 \%$ and was found to be between $5-10 \mathrm{ng} / \mathrm{mL}$ in 15 cases i.e. 60\%. Serum PSA level, in Prostate carcinoma patients was found to be between $21-40 \mathrm{ng} / \mathrm{mL}$ in 8 cases i.e. $32 \%$. Serum PSA level was found to be between $5-20 \mathrm{ng} / \mathrm{mL}$ in 6 cases i.e. $24 \%$; was found to be between $41-60 \mathrm{ng} / \mathrm{mL}$ in 5 cases i.e. $20 \%$; was found to be between $81-100 \mathrm{ng} / \mathrm{mL}$ in 3 cases i.e. $12 \%$; was found to be $>100 \mathrm{ng} / \mathrm{mL}$ in 2 cases i.e. $8 \%$ and between $61-80 \mathrm{ng} / \mathrm{mL}$ in 1 case i.e. $4 \%$. (Table 11 ).

Serum TSH level in all the BPH patients was found to be within normal limits. It was found to be between 1.0-3.0 $\mu \mathrm{IU} / \mathrm{mL}$ in 24 cases i.e. $96 \%$ and was found to be between 0.3 to $0.9 \mu \mathrm{IU} / \mathrm{mL}$ in 1 case i.e. $4 \%$. (Table 12 ).

Serum TSH level in Prostate carcinoma patients: it was found to be within normal limits in most of the cases. It was found to be between $1.0-3.0 \mu \mathrm{IU} / \mathrm{mL}$ in 22 cases i.e. $88 \%$ and was found to be between 0.3 to $0.9 \mu \mathrm{IU} / \mathrm{mL}$ in 1 case i.e., $4 \%$. It was found to be increased i.e. $>5.0 \mu \mathrm{IU} / \mathrm{mL}$ in only 2 cases $(8 \%)$ and serum PSA level was $>100 \mathrm{ng} / \mathrm{mL}$. (Table 12). These two cases were associated with osteoblastic secondaries in iliac bone and histopathologically was found to be high-grade tumour with Gleason score 8.

In CA prostate patients, histopathological findings showed well-differentiated tumour in 17 cases $(68 \%)$, intermediate-grade tumour in 6 cases $(24 \%)$ and high-grade tumour in 2 cases (8\%). (Table 13).

Gleason score, in Prostate carcinoma patients was found to be between 2 to 4 in 17 cases (68\%) and to be between 5 to 7 in 6 cases (24\%) and between 8 to 10 in 2 cases (8\%). (Table 14).

\begin{tabular}{|c|c|c|c|c|c|}
\hline \multirow{2}{*}{$\begin{array}{c}\text { Sl. } \\
\text { No. }\end{array}$} & \multirow{2}{*}{$\begin{array}{c}\text { Age } \\
\text { (years) }\end{array}$} & $\begin{array}{c}\text { No. of } \\
\text { Cases }\end{array}$ & Percent & $\begin{array}{c}\text { No. of } \\
\text { Cases }\end{array}$ & Percent \\
\hline 1. & $<50$ & 1 & 4 & Nil & 0 \\
\hline 2. & $51-60$ & 7 & 28 & 3 & 12 \\
\hline 3. & $61-70$ & 7 & 28 & 13 & 52 \\
\hline 4. & $71-80$ & 9 & 36 & 6 & 24 \\
\hline 5. & $>80$ & 1 & 4 & 3 & 12 \\
\hline \multicolumn{6}{|c|}{ Table 1. Distribution of Patients According to } \\
their Age Groups
\end{tabular}




\begin{tabular}{|c|c|c|c|c|c|c|c|c|c|c|c|c|c|}
\hline \multirow{3}{*}{$\begin{array}{c}\text { Sl. } \\
\text { No. }\end{array}$} & \multirow{3}{*}{$\begin{array}{c}\text { Urinary Symptom } \\
\text { (Symptom Score } \\
\text { Criteria) }\end{array}$} & \multicolumn{12}{|c|}{ AUA Score } \\
\hline & & \multicolumn{2}{|c|}{$\begin{array}{c}\text { Not at all } \\
0\end{array}$} & \multicolumn{2}{|c|}{$\begin{array}{c}<1 \text { time } \\
1\end{array}$} & \multicolumn{2}{|c|}{$\begin{array}{c}\text { Less than Half } \\
\text { a time } \\
2\end{array}$} & \multicolumn{2}{|c|}{$\begin{array}{l}\text { About Half a } \\
\text { Time } 3\end{array}$} & \multicolumn{2}{|c|}{$\begin{array}{c}>\text { Half the time } \\
4\end{array}$} & \multicolumn{2}{|c|}{$\begin{array}{c}\text { Almost always } \\
5\end{array}$} \\
\hline & & No. & $\%$ & No. & $\%$ & No. & $\%$ & No. & $\%$ & No. & $\%$ & No. & $\%$ \\
\hline 1. & $\begin{array}{l}\text { Sensation of incomplete } \\
\text { emptying of urinary } \\
\text { bladder }\end{array}$ & Nil & 0 & Nil & 0 & 3 & 12 & 4 & 16 & 8 & 32 & 10 & 40 \\
\hline 2. & Frequency & 2 & 8 & 3 & 12 & 12 & 48 & 7 & 28 & 2 & 8 & 1 & 4 \\
\hline 3. & Intermittency & 2 & 8 & 1 & 4 & 1 & 0 & 6 & 24 & 3 & 12 & 13 & 52 \\
\hline 4. & Urgency & 3 & 12 & $\mathrm{Nil}$ & 0 & 5 & 20 & 4 & 16 & 7 & 28 & 6 & 24 \\
\hline 5. & Weak urinary stream & Nil & 0 & $\mathrm{Nil}$ & 0 & 1 & 4 & 5 & 20 & 9 & 36 & 10 & 40 \\
\hline 6. & Hesitancy/straining & Nil & 0 & Nil & 0 & 5 & 20 & 7 & 28 & 4 & 16 & 9 & 36 \\
\hline 7. & Nocturia & 2 & 8 & $\mathrm{Nil}$ & 0 & 3 & 12 & 7 & 28 & 9 & 36 & 4 & 16 \\
\hline
\end{tabular}

\begin{tabular}{|c|c|c|c|c|c|c|c|c|c|c|c|c|c|}
\hline \multirow{3}{*}{$\begin{array}{l}\text { Sl. } \\
\text { No. }\end{array}$} & \multirow{3}{*}{$\begin{array}{c}\text { Urinary Symptom } \\
\text { (Symptom Score Criteria) }\end{array}$} & \multicolumn{12}{|c|}{ AUA Score } \\
\hline & & \multicolumn{2}{|c|}{$\begin{array}{c}\text { Not at all } \\
\quad 0\end{array}$} & \multicolumn{2}{|c|}{$\begin{array}{c}<1 \text { time } \\
1\end{array}$} & \multicolumn{2}{|c|}{$\begin{array}{c}\text { Less than } \\
\text { Half a time } \\
2\end{array}$} & \multicolumn{2}{|c|}{$\begin{array}{c}\text { About Half a } \\
\text { time } \\
3 \\
\end{array}$} & \multicolumn{2}{|c|}{$\begin{array}{c}>\text { Half the } \\
\text { time } \\
4\end{array}$} & \multicolumn{2}{|c|}{$\begin{array}{c}\text { Almost } \\
\text { always } \\
5\end{array}$} \\
\hline & & No. & $\%$ & No. & $\%$ & No. & $\%$ & No. & $\%$ & No. & $\%$ & No. & $\%$ \\
\hline 1. & $\begin{array}{l}\text { Sensation of incomplete } \\
\text { emptying of urinary bladder }\end{array}$ & Nil & 0 & Nil & 0 & 1 & 4 & 5 & 20 & 9 & 36 & 10 & 40 \\
\hline 2. & Frequency & 1 & 4 & Nil & 0 & 8 & 36 & 7 & 28 & 4 & 16 & 5 & 20 \\
\hline 3. & Intermittency & 2 & 8 & Nil & 0 & 3 & 12 & 4 & 16 & 6 & 24 & 10 & 40 \\
\hline 4. & Urgency & 2 & 8 & Nil & 0 & 7 & 28 & 5 & 20 & 3 & 12 & 8 & 32 \\
\hline 5. & Weak urinary stream & Nil & 0 & Nil & 0 & 2 & 8 & 6 & 24 & 8 & 32 & 9 & 36 \\
\hline 6. & Hesitancy/straining & Nil & 0 & Nil & 0 & Nil & 0 & 4 & 16 & 10 & 40 & 11 & 44 \\
\hline 7. & Nocturia & 1 & 4 & Nil & 0 & Nil & 0 & 2 & 8 & 10 & 40 & 12 & 48 \\
\hline
\end{tabular}

\begin{tabular}{|c|c|c|c|c|c|}
\hline \multirow{2}{*}{$\begin{array}{c}\text { Sl. } \\
\text { No. }\end{array}$} & \multirow{2}{*}{ Symptoms } & \multicolumn{2}{|c|}{ BPH } & \multicolumn{2}{c|}{ Ca-Prostate } \\
\cline { 3 - 6 } & $\begin{array}{c}\text { No. of } \\
\text { Cases }\end{array}$ & $\%$ & $\begin{array}{c}\text { No. of } \\
\text { Cases }\end{array}$ & $\%$ \\
\hline 1. & Nausea & 13 & 52 & 6 & 24 \\
\hline 2. & Vomiting & 3 & 12 & 1 & 4 \\
\hline 3. & $\begin{array}{c}\text { Abdominal } \\
\text { distension }\end{array}$ & 1 & 4 & Nil & 0 \\
\hline 4. & \multicolumn{6}{|c|}{ Malaise } & 17 & 68 & 10 & 40 \\
\hline \multicolumn{6}{|c|}{ Table 4. Associated Symptoms in Cases of BPH and } \\
Prostate Carcinoma \\
\hline
\end{tabular}

\begin{tabular}{|c|c|c|c|c|c|}
\hline \multirow{2}{*}{$\begin{array}{c}\text { Sl. } \\
\text { No. }\end{array}$} & \multirow{2}{*}{$\begin{array}{c}\text { Blood urea } \\
\text { (mg\%) }\end{array}$} & \multicolumn{2}{|c|}{ BPH } & \multicolumn{2}{c|}{$\begin{array}{c}\text { Prostate } \\
\text { carcinoma }\end{array}$} \\
\cline { 3 - 6 } & & No. & \% & No. & $\%$ \\
\hline 1. & $20-30$ & 10 & 40 & 12 & 48 \\
\hline 2. & $31-40$ & 6 & 24 & 6 & 24 \\
\hline 3. & $41-50$ & 5 & 20 & 5 & 20 \\
\hline 4. & $51-60$ & 5 & 12 & Nil & 0 \\
\hline 5. & $>60$ & 1 & 4 & 2 & 8 \\
\hline \multicolumn{3}{|c|}{ Table 5. Blood Urea in Cases of BPH and Prostate } \\
Carcinoma \\
\hline
\end{tabular}

\begin{tabular}{|c|c|c|c|c|c|}
\hline \multirow{2}{*}{$\begin{array}{c}\text { Sl. } \\
\text { No. }\end{array}$} & $\begin{array}{c}\text { Serum } \\
\text { Creatinine } \\
\text { Level (mg\%) }\end{array}$ & No. & $\mathbf{0}$ & No. & $\%$ \\
\cline { 3 - 6 } & $<1.5$ & 22 & 88 & 24 & 96 \\
\hline 1. & $1.5-3$ & 3 & 12 & 1 & 4 \\
\hline 3. & $>3$ & Nil & 0 & Nil & 0 \\
\hline 3. & Ca Prostate \\
\hline \multicolumn{7}{|c|}{ Table 6. Serum Creatinine in Cases of BPH and Prostate } \\
Carcinoma
\end{tabular}

\begin{tabular}{|c|c|c|c|c|c|c|c|}
\hline \multirow{2}{*}{\multicolumn{4}{|c|}{ Digital Rectal Examination }} & \multicolumn{2}{|c|}{ BPH } & \multicolumn{2}{|c|}{ Ca-prostate } \\
\hline & & & & \multirow{2}{*}{$\begin{array}{l}\text { No. } \\
\text { Nil }\end{array}$} & \multirow{2}{*}{$\begin{array}{c}\% \\
0\end{array}$} & \multirow{2}{*}{\begin{tabular}{|c|} 
No. \\
18
\end{tabular}} & \multirow{2}{*}{\begin{tabular}{|l|}
$\%$ \\
72
\end{tabular}} \\
\hline \multirow{2}{*}{\multicolumn{2}{|c|}{ Consistency }} & \multicolumn{2}{|c|}{ Hard } & & & & \\
\hline & & \multicolumn{2}{|c|}{ Firm } & 25 & 100 & 7 & 28 \\
\hline \multirow{3}{*}{\multicolumn{2}{|c|}{$\begin{array}{c}\text { Size of } \\
\text { prostate on } \\
\text { clinical } \\
\text { examination }\end{array}$}} & \multicolumn{2}{|c|}{$\begin{array}{c}\text { Mild (upper limit } \\
\text { reached easily) }\end{array}$} & 8 & 32 & Nil & 0 \\
\hline & & \multicolumn{2}{|c|}{\begin{tabular}{|c|} 
Moderate (upper \\
limit just \\
reached)
\end{tabular}} & 17 & 68 & 15 & 60 \\
\hline & & \multicolumn{2}{|c|}{$\begin{array}{l}\text { Gross (upper } \\
\text { limit not } \\
\text { reached) }\end{array}$} & Nil & 0 & 10 & 40 \\
\hline \multicolumn{2}{|c|}{ Nodularity } & \multicolumn{2}{|c|}{ Nodularity } & Nil & 0 & 15 & 60 \\
\hline \multirow{2}{*}{\multicolumn{2}{|c|}{$\begin{array}{l}\text { Fixation of } \\
\text { mucosa }\end{array}$}} & \multicolumn{2}{|c|}{ Free } & 25 & 100 & 9 & 36 \\
\hline & & \multicolumn{2}{|c|}{ Adherent } & Nil & & 16 & 64 \\
\hline \multirow{2}{*}{\multicolumn{2}{|c|}{ Prostate }} & \multicolumn{2}{|c|}{ Mobile } & 25 & 100 & 7 & 28 \\
\hline & & \multicolumn{2}{|c|}{ Fixed } & Nil & 0 & 18 & 72 \\
\hline \multirow{2}{*}{\multicolumn{2}{|c|}{ Median groove }} & \multicolumn{2}{|c|}{\begin{tabular}{|l|} 
Obliterated \\
\end{tabular}} & Nil & & 17 & 68 \\
\hline & & \multicolumn{2}{|c|}{\begin{tabular}{|l|} 
Non-obliterated \\
\end{tabular}} & 25 & 10 & 8 & 32 \\
\hline Tab & e 7. Distr & $\begin{array}{l}\text { ibution of } \\
\text { heir Digito }\end{array}$ & Rectal & $\begin{array}{l}\text { S Accc } \\
\text { Exan }\end{array}$ & & $\begin{array}{l}g \text { to Fine } \\
\text { ion }\end{array}$ & lings in \\
\hline & & & & SPH & & Ca-pr & ostate \\
\hline $\begin{array}{l}\text { Sl. } \\
\text { No. }\end{array}$ & Finc & dings & $\begin{array}{l}\text { No. of } \\
\text { cases }\end{array}$ & Per & ent & $\begin{array}{l}\text { No. of } \\
\text { cases }\end{array}$ & Percent \\
\hline 1. & $\mathrm{BPH}$ & Grade I & 6 & & & Nil & 0 \\
\hline 2. & $\mathrm{BPH} \mathrm{C}$ & Grade II & 11 & & & 8 & 32 \\
\hline 3. & BPH G & rade II+ & 8 & 3 & & 8 & 32 \\
\hline 4. & Irregula & r prostate & Nil & ( & & 9 & 36 \\
\hline
\end{tabular}




\begin{tabular}{|c|c|c|c|c|c|}
\hline \multirow{2}{*}{$\begin{array}{c}\text { Sl. } \\
\text { No. }\end{array}$} & \multirow{2}{*}{ Findings } & \multicolumn{2}{|c|}{ BPH } & \multicolumn{2}{c|}{ CA-prostate } \\
\cline { 2 - 6 } & No. & $\mathbf{\%}$ & No. & $\%$ \\
\hline 1. & Mild enlargement & 8 & 28 & Nil & 0 \\
\hline 2. & $\begin{array}{c}\text { Moderate } \\
\text { enlargement }\end{array}$ & 17 & 72 & 12 & 48 \\
\hline 3. & Gross enlargement & Nil & 0 & 13 & 52 \\
\hline \multicolumn{2}{|c|}{ Table 9. USG Findings in Cases of BPH and CA-Prostate } \\
\hline
\end{tabular}

\begin{tabular}{|c|c|c|c|c|c|}
\hline \multirow{2}{*}{$\begin{array}{l}\text { Sl. } \\
\text { No. }\end{array}$} & \multirow[b]{2}{*}{ Findings } & \multicolumn{2}{|c|}{ BPH } & \multicolumn{2}{|c|}{ CA-prostate } \\
\hline & & $\begin{array}{l}\text { No. of } \\
\text { cases }\end{array}$ & Percent & $\begin{array}{l}\text { No. of } \\
\text { cases }\end{array}$ & Percent \\
\hline 1. & Normal & 23 & 92 & 21 & 84 \\
\hline 2. & Left ureteric stone & 2 & 8 & 1 & 4 \\
\hline 3. & Left renal stone & - & - & 1 & 4 \\
\hline 4. & $\begin{array}{c}\text { Osteoblastic } \\
\text { secondaries in iliac } \\
\text { bone }\end{array}$ & - & - & 2 & 8 \\
\hline \multicolumn{6}{|c|}{$\begin{array}{c}\text { Table 10. X-ray KUB Findings in Cases of BPH and CA- } \\
\text { Prostate }\end{array}$} \\
\hline
\end{tabular}

\begin{tabular}{|c|c|c|c|c|c|}
\hline \multirow{2}{*}{$\begin{array}{c}\text { Sl. } \\
\text { No. }\end{array}$} & \multirow{2}{*}{$\begin{array}{c}\text { PSA level } \\
\text { (ng/mL) }\end{array}$} & $\begin{array}{c}\text { BPH } \\
\text { cases }\end{array}$ & Percent & $\begin{array}{c}\text { CA-prostate } \\
\text { cases }\end{array}$ & Percent \\
\hline 1. & $0-4$ & 10 & 40 & Nil & 0 \\
\hline 2. & $5-20$ & 15 & 60 & 6 & 24 \\
\hline 3. & $21-40$ & Nil & 0 & 8 & 32 \\
\hline 4. & $41-60$ & Nil & 0 & 5 & 20 \\
\hline 5. & $61-80$ & Nil & 0 & 1 & 4 \\
\hline 6. & $81-100$ & Nil & 0 & 3 & 12 \\
\hline 7. & $>100$ & Nil & 0 & 2 & 8 \\
\hline
\end{tabular}

Table 11. Distribution of Patients According to their Serum PSA Levels (Normal Value - <4 ng/mL)

\begin{tabular}{|c|c|c|c|c|c|}
\hline \multirow{2}{*}{$\begin{array}{c}\text { Sl. } \\
\text { No. }\end{array}$} & TSH level $(\boldsymbol{\mu I U} / \mathbf{m L})$ & \multicolumn{2}{|c|}{ BPH } & \multicolumn{2}{c|}{ CA-prostate } \\
\cline { 3 - 6 } & & No. of & Percent & $\begin{array}{c}\text { No. of } \\
\text { cases }\end{array}$ & Percent \\
\hline 1. & $0.3-0.9$ & 1 & 4 & 1 & 4 \\
\hline 2. & $1.0-3.0$ & 24 & 96 & 22 & 88 \\
\hline 3. & $3.1-5.0$ & Nil & 0 & Nil & 0 \\
\hline 4. & $>5.0$ & Nil & 0 & 2 & 8 \\
\hline
\end{tabular}

Table 12. Distribution of Patients According to their Serum TSH level (Normal Value 0.3-5.0 $\mu \mathrm{IU} / \mathrm{mL}$ )

\begin{tabular}{|c|c|c|c|}
\hline \multirow{2}{*}{$\begin{array}{c}\text { Sl. } \\
\text { No. }\end{array}$} & \multirow{2}{*}{ Grading of Tumour } & \multicolumn{2}{|c|}{ CA-prostate } \\
\cline { 3 - 4 } & & No. of cases & Percent \\
\hline 1. & Well-differentiated tumour & 17 & 68 \\
\hline 2. & Intermediate-grade tumour & 6 & 24 \\
\hline 3. & High-grade tumour & 2 & 8 \\
\hline \multicolumn{3}{|c|}{ Table 13. Distribution of Patients According to their } \\
Histopathological Examination \\
\hline
\end{tabular}

\begin{tabular}{|c|c|c|c|}
\hline \multirow{2}{*}{$\begin{array}{c}\text { Sl. } \\
\text { No. }\end{array}$} & \multirow{2}{*}{ Score } & $\begin{array}{c}\text { CA-prostate } \\
\text { Cases }\end{array}$ & Percent \\
\hline 1. & 2 to 4 & 17 & 68 \\
\hline 2. & 5 to 6 & 6 & 24 \\
\hline 3. & 7 & 0 & 0 \\
\hline 4. & 8 to 10 & 2 & 8 \\
\hline \multicolumn{3}{|c|}{ Table 14. Distribution of Patients According to their } \\
Gleason Score \\
\hline
\end{tabular}

\section{DISCUSSION}

A total of 50 patients were studied, of which 25 were BPH Patients and 25 were of CA Prostate. In Prostate carcinoma, all of the patients had complaints of sensation of incomplete emptying of urinary bladder, weak urinary stream and hesitancy $(100 \%)$ followed by frequency and nocturia (96\%), intermittency and urgency (92\%), dysuria (88\%), burning micturition $(76 \%)$, haematuria $(20 \%)$ and retention of urine in $16 \%$ cases.

A symptom index for benign prostatic hyperplasia (BPH) was developed and validated by a multidisciplinary measurement committee of the American Urological Association (AUA). Validation studies were conducted involving a total of $210 \mathrm{BPH}$ patients and 108 control subjects. The final AUA symptom index includes 7 questions covering frequency, nocturia, weak urinary stream, hesitancy, intermittence, incomplete emptying and urgency.[6]

\section{AUA Symptom Score - Sum of Questions $A_{1}$ to $A_{7}$ i.e.}

1. Incomplete emptying: Over the past month, how often have you had a sensation of not emptying your bladder completely after you finished urinating?

2. Frequency: Over the past month, how often have you had to urinate again in less than two hours after you finished urinating?

3. Intermittency: Over the past month, how often have you stopped and started again several times when you urinate?

4. Urgency: Over the past month, how often have you found it difficult to postpone urination?

5. Weak stream: Over the past month, how often have you had a weak urinary stream?

6. Straining/hesitancy: Over the past month, how often have you had to push or strain to begin urination?

7. Nocturia: Over the past month, how many times did you most typically get up to urinate from the time you went to bed at night until the time you got up in the morning?

AUA score of patients of BPH and CA-prostate are shown in Table 2 and Table 3.

In $\mathrm{BPH}, 84 \%$ cases were vegetarians and $48 \%$ were smokers and $12 \%$ were alcoholics.

In Prostate carcinoma, 72\% cases were vegetarians, $64 \%$ were smokers and $28 \%$ were alcoholics.

In our study, the increased number of vegetarians suffering from Prostate carcinoma and BPH was noted. This finding may be due to fact that most of the population in this area consisted vegetarians.

High intake of dietary fat, especially, high intake of animal and saturated fats, may be associated with increased prostate cancer risk. In contrast, a low-fat diet, specifically low in saturated fat, may be beneficial for prostate cancer survivors by reducing tumour angiogenesis and cancer recurrence. The insulin-like growth factor (IGF)/Akt signalling pathway appears to be the key pathway moderating dietary fat intake and prostate cancer development and progression. [7]

In our study, $64 \%$ cases of Prostate carcinoma and $48 \%$ cases of BPH were smokers. Studies of prostate cancer mortality have consistently found that smoking is associated with higher risk, with more recent smoking being more strongly associated.[8] 
Findings of DRE were as per Table 7.

Prostate cancer spread has predictable patterns, known to affect the prostatic contours. Of the asymmetrical contours, $55(34 \%)$ were caused by cancer, and of the cancer foci, 55 (20\%) generated asymmetrical contours. ${ }^{[9]}$

One of the physical sign of a malignant prostate is asymmetry of gland. The finding of a patient with a relatively early prostate cancer is suggested by a firm nodule in one of the prostate lobes. As it enlarges, it may occupy the whole of one lobe and/or extend posteriorly to invade one or both of the seminal vesicles, giving extension shaped like horns of a bull. The central sulcus may be distorted or lost altogether and the rectal mucosa may become fixed to the gland. As the disease becomes more extensive, it may also invade both prostatic lobes and be felt as a hard, irregular, nodular structure with extensions of tumour laterally to the pelvic walls and these fixed the position of gland within the pelvis.

Bone survey films (skeletal radiography) are insensitive as a method to screen for the presence of bone metastasis. Lentle and co-workers (1974) demonstrated that $50 \%$ of the bone density must be replaced by tumour before standard radiographic imaging method identifies distant spread. Skeletal radiography is recommended only for confirmation of a positive bone scan in men in whom bony metastasis are not suspected at initial evaluation. [10]

Many of the men presenting with prostate cancer may have metastasis at time of diagnosis, the commonest site for these being in the bones. The lumbar spine is often affected and deposits of metastatic tissue may invade or compress the spinal cord and give rise to lower limb neurological signs. Other physical signs that may be associated with a diagnosis of advanced prostate cancer include a hydronephrotic kidney due to unilateral or bilateral ureteric obstruction and signs of renal impairment.

As general guidelines, the majority of men (70-80\%) with PSA values less than $4.0 \mathrm{ng} / \mathrm{mL}$ have pathologically organconfined disease, more than $50 \%$ of men with PSA levels greater than $10.0 \mathrm{ng} / \mathrm{mL}$ already have established capsular penetration and more men (75\%) with serum PSA levels greater than $50 \mathrm{ng} / \mathrm{mL}$ have positive pelvic lymph node.[11]

Although the overall positive predictive value of the DRE was poor, most patients diagnosed with prostate cancer had an abnormality on the DRE that corresponded either to the location of cancer detected on biopsy or had cancer volumes on prostatectomy specimens large enough to be palpable. Higher serum PSA levels even if less than $4.0 \mathrm{ng} / \mathrm{mL}$ were associated with dramatic increases in prostate cancer detection. [12]

High serum TSH levels in men with Gleason 8 prostate cancer is a result of the elaboration of TSH by cancer cells. Bone mineral density in the face of normal levels of thyroid hormone depends on an intact response to TSH, which ordinarily suppresses both osteoblast and osteoclast differentiation, thereby exerting control over bone remodelling. However, with abnormally high TSH levels this process may become deranged, promoting the development of bone metastases. If TSH production by prostate cancer cells could be suppressed, the incidence of bone metastases might be reduced. [13]
In a study by Sawin CT et al, done in 344 relatively healthy persons older than 60 years, 22 (5-9\%) had a clearly elevated level of serum thyrotropin (TSH) (greater than 10 $\mu \mathrm{IU} / \mathrm{mL}$ ), a finding more common in women than in men. A further $14.4 \%$ had a slightly elevated level of serum TSH $(>5$ and $\leq 10 \mu \mathrm{IU} / \mathrm{mL}$ ). The study did not find any correlation between elevated serum TSH and prostatic malignancy. [13]

In a prospective study, Phadke MA et al estimated serum prolactin, TSH, LH, FSH and inhibin level using radioimmunoassay, in normal subjects and in patients with benign prostatic hyperplasia (BPH), before and after tumour resection. In cases of benign prostatic hyperplasia, no significant changes in the level of TSH were noted after surgery.[14]

In another prospective study by Salminen et al (2004), levels of serum thyroid stimulating hormones (TSH), free thyroxine $\left(\mathrm{fT}_{4}\right)$ and thyroid binding globulin concentrations were measured in prostate cancer patients treated with either radiotherapy and androgen deprivation for 12 months (AD) or radical radiotherapy alone. The study concluded that prolonged use of $\mathrm{AD}$ hampers the interpretation of thyroid test results by causing a significant decline in $\mathrm{fT}_{4}$ at 6 and 12 months.[15]

A study by Frokovic et al (1994) reported development of TSH-secreting small cell prostate cancer (SCPC) from highgrade adenocarcinoma (Gleason score 8) with an elevated number of chromogranin A positive cells located in benign structures adjacent to the cancer. Conversion to SCPC was followed up during 4 years. The study concluded (i) extremely poor prognosis associated with high grade adenocarcinomas that demonstrate stronger immunohistochemical positivity for prostatic acid phosphatase (PAP) than for PSA, (ii) chromogranin A positive cells in benign structures adjacent to the cancer as a possible paracrine promoter of SCPC from poorly differentiated adenocarcinoma. [16]

In yet another study, Aprikian et al (1994) attempted to determine the correlation of neuroendocrine differentiation and deoxyribonucleic acid content in lymph node and skeletal metastasis. They immunohistochemically examined 62 metastatic lesions (41 pelvic lymph nodes and 21 bone metastases) for the presence of chromogranin-A expressing tumour cells. Of 41 lymph nodes and 21 bone metastases, 19 (46\%) and 11 (52\%) respectively contained chromogranin-A immunoreactive cells. Peptide hormone immunocytochemistry in 19 cases (12 lymph nodes and 7 bone metastases) demonstrated neuroendocrine cells containing TSH in 17 (89\%) cases.[17]

\author{
Abbreviations \\ TSH - Thyroid Stimulating Hormone \\ PSA - Prostate Specific Antigen \\ BPH - Benign Prostatic Hyperplasia \\ CA Prostate - Prostate carcinoma \\ DRE - Digital Rectal Examination \\ TURP - Trans-urethral Resection of Prostate \\ EDA - Exploratory data analysis \\ AUA - American Urology Association \\ X-ray KUB - X-ray of Kidney, Ureter and Bladder Region.
}




\section{CONCLUSION}

Serum PSA level in most of the BPH patients was found to be within normal limits and serum TSH level in all of the BPH patients was found to be within normal limits.

Serum PSA level in all the Prostate carcinoma patients was found to be increased and it was found to be $>100 \mathrm{ng} / \mathrm{mL}$ in only $8 \%$ cases of Prostate carcinoma. Serum TSH level in most of the Prostate carcinoma patients was found to be within normal limits and it was found to be increased only in 8\% cases of Prostate carcinoma. Histopathology in Prostate carcinoma patients was found to be well differentiated with tumour with Gleason score 2 to 4 in $68 \%$ cases followed by intermediate-grade tumour with Gleason score 5 to 6 in $24 \%$ cases followed by high-grade tumour with Gleason score 8 in only $8 \%$ cases and in these $8 \%$ cases there was associated skeletal metastases (osteoblastic secondaries in iliac bone).

By this study, it is hereby concluded that only in $8 \%$ cases of Prostate carcinoma, patients had very high PSA level $(>100$ $\mathrm{ng} / \mathrm{mL}$ ) as well as increased serum TSH level and these cases were associated with Gleason score 8 (high-grade tumour) and skeletal metastases.

Further statistical/epidemiological studies are required for confirmation of these findings.

\section{REFERENCES}

[1] Abe E, Marians RC, $\mathrm{Yu} \mathrm{W}$, et al. TSH is a negative regulator of skeletal remodeling. Cell 2003;115(2):151-62.

[2] Roodman GD. Mechanisms of bone metastasis. N Engl J Med 2004;350(16):1655-64.

[3] Humphrey PA. Gleason grading and prognostic factors in carcinoma of the prostate. Mod Pathol 2004;17(3):292-306.

[4] Chen N, Zhou Q. The evolving Gleason grading system. Chin J Cancer Res 2016;28(1):58-64.

[5] Reiter RE, deKernion JB. Epidemiology etiology. Prevention of prostate cancer. In: Walsh PC, Retik AB, Vaughan ED, et al. (eds). Campbell's urology. $8^{\text {th }}$ edn. Vol. 4. Philadelphia, London New York, St. Louis, Sydney, Toronto: Saunders, 2002:3003-24.

[6] Barry MJ, Fowler FJ, O'leary MP, et al. The American urological association symptom index for benign prostatic hyperplasia. J Urol 2017;197(2S):S189-97.
[7] Di Sebastiano KM, Mourtzakis M. The role of dietary fat throughout the prostate cancer trajectory. Nutrients 2014;6(12):6095-109.

[8] Wilson KM, Giovannucci EL, Mucci LA. Lifestyle and dietary factors in the prevention of lethal prostate cancer. Asian J Androl 2012;14(3):365-74.

[9] Kiyoshima K, Oda Y, Tamiya S, et al. Histopathological approach to prostatic contour alterations with the concept of left-right asymmetry. Pathol Int 2006;56(7):390-6.

[10] Lentle BC, McGowan DG, Dierich H. Technetium-99M polyphosphate bone scanning in carcinoma of the prostate. Br J Urol 1974;46(5):543-8.

[11] Partin AW, Pound CR, Clemens JQ, et al. Serum PSA after anatomic radical prostatectomy. The Johns Hopkins experience after 10 years. Urol Clin North Am 1993;20(4):713-25.

[12] Bozeman CB, Carver BS, Caldito G, et al. Prostate cancer in patients with an abnormal digital rectal examination and serum prostate-specific antigen less than $4.0 \mathrm{ng} / \mathrm{mL}$. Urology 2005;66(4):803-7.

[13] Sawin CT, Chopra D, Azizi F, et al. The aging thyroid. Increased prevalence of elevated serum thyrotropin levels in the elderly. JAMA 1979;242(3):247-50.

[14] Phadke MA, Vanage GR, Sheth AR. Circulating levels of inhibin, prolactin, TSH, LH and FSH in benign prostatic hypertrophy before and after tumor resection. Prostate 1987;10(2):115-22.

[15] Salminen E, Koskinen A, Backman H, et al. Effect of adjuvant androgen deprivation on thyroid function tests in prostate cancer patients. Anticancer Drugs 2004;15(4):351-6.

[16] Frokovic-Grazio S, Kraljic I, Trnski D, et al. Immunohistochemical staining and serotest markers during development of a sarcomatoid and small cell prostate tumor. Anticancer Res 1994;14(5B):2151-6.

[17] Aprikian AG, Cordon-Cardo C, Fair WR, et al. Neuroendocrine differentiation in metastatic prostatic adenocarcinoma. J Urol 1994;151(4):914-9.

[18] Lehrer S, Diamond EJ, Stone NN, et al. Serum thyroidstimulating hormone is elevated in men with Gleason 8 prostate cancer. BJU Int 2005;96(3):328-9. 